\title{
ANALISIS LOGAM TIMBAL (Pb) DAN KONSENTRASI KLOROFIL PADA ALGA Padina australis Hauck DARI PERAIRAN TELUK TOTOK DAN PERAIRAN BLONGKO, PROVINSI SULAWESI UTARA
}

\author{
(An Analysis of Lead (Pb) Concentration and Chlorophyll Concentration in Algae of \\ Padina australis Hauck from Totok Bay and Blongko Water in North Sulawesi Province)
}

\author{
Batar Siahaan $^{1 *}$, Desy M.H. Mantiri ${ }^{1}$, Joice R.T.S.L. Rimper ${ }^{1}$ \\ 1. Program Studi IImu Kelautan Fakultas Perikanan dan IImu Kelautan Universitas Sam \\ Ratulangi, Manado. \\ *e-mail : batarsiahaan60@gmail.com
}

The aims of this study are to analyze the $\mathrm{Pb}$ concentrations in water and sediment of Totok Bay known as gold mining area and Blongko water where a marine protected area exist, and to analyze chlorophyll pigment and $\mathrm{Pb}$ concentrations in tissue of Padina australis Hauck taken from these two locations. The analysis of $\mathrm{Pb}$ concentrations was based on American Public Health Association (APHA) method, while chlorophyll pigment analysis was conducted using spectrophotometer with a 95\% acetone prior treatment. The results revealed that $\mathrm{Pb}$ concentration in water and sediment from Blongko Water was $4.4 \mathrm{ppm}$ and $22.6 \mathrm{ppm}$ from Totok Bay or five times higher than those from Blongko Water. Concentration of $\mathrm{Pb}$ in tissue of P.australis Hauck from Totok Bay was $3.8 \mathrm{ppm}$, higher than those from Blongko Water that was only $1.1 \mathrm{ppm}$. Meanwhile, average concentrations of chlorophyll a and c pigments in the algae tissue from Totok Bay were $19.073 \mathrm{~g} / \mathrm{ml}$ for chlorophyll-a and $1.275 \mathrm{~g} / \mathrm{ml}$ chlorophyll-c, such concentrations were higher than the average concentrations in alga tissues collected from Blongko Water that were $7.296 \mathrm{~g} / \mathrm{ml}$ of chlorophyll-a and 0.975 of chlorophyll-c. This study showed that algae from contaminated water of Totok Bay carried out photosynthesis process to survive.

Keywords: lead, chlorophyll, Totok Bay, Blongko Waters

Penelitian ini dilakukan dengan tujuan untuk menganalisis kandungan logam timbal $(\mathrm{Pb})$ pada air, sedimen, dan thallus alga serta mengetahui konsentrasi pigmen klorofil pada alga Padina australis Hauck yang terdapat di Perairan Teluk Totok dan Perairan Blongko. Perairan Teluk Totok merupakan perairan tempat buangan limbah pertambangan, sedangkan Perairan Blongko adalah perairan yang relatif bersih dan termasuk dalam Daerah Perlindungan Laut. Analisis logam timbal $(\mathrm{Pb})$ pada air, sedimen, dan thallus alga berdasarkan metode standar American Public Health Association (APHA) dan analisis pigmen klorofil total yaitu dalam aseton $95 \%$ dengan menggunakan spektrofotometer. Hasil penelitian menunjukkan bahwa analisis konsentrasi logam timbal $(\mathrm{Pb})$ telah terdeteksi pada dua perairan, di sedimen Perairan Blongko sebesar 4,4 ppm dan Perairan Teluk Totok keberadaan logam timbal lima kali lebih banyak yaitu sebesar $22,6 \mathrm{ppm}$. Analisis logam pada Thallus alga P.australis Hauck di Perairan Teluk Totok sebesar 3,8 ppm, lebih tinggi dibandingkan dengan konsentrasi timbal $(\mathrm{Pb})$ dalam thallus $P$. australis Hauck dari Perairan Blongko yaitu sebesar $1,1 \mathrm{ppm}$. Nilai ratarata konsentrasi pigmen klorofil a dan c di Perairan Teluk Totok adalah $19.073 \mathrm{~g} / \mathrm{ml}$ klorofil a dan $1.275 \mathrm{~g} / \mathrm{ml}$ klorofil c lebih tinggi dibandingkan dengan nilai rata-rata pigmen klorofil di Perairan Blongko yaitu $7.296 \mathrm{~g} / \mathrm{ml}$ klorofil a dan 0.975 klorofil c. Perairan yang telah terkontaminasi logam, alga yang hidup didalamnya mampu melakukan proses fotosintesis untuk mempertahankan hidup.

Kata kunci: timbal, klorofil, Teluk Totok, Perairan Blongko 


\section{PENDAHULUAN}

Perairan laut Indonesia memegang peranan penting karena memiliki nilai strategis berupa potensi sumberdaya alam dan jasa-jasa lingkungan.pesisir. Indonesia mempunyai perairan laut yang lebih luas dari daratan, oleh karena itu dikenal sebagai negara maritim. Kekayaan laut Indonesia dapat saja mengalami pengurangan sebab mendapatkan pengaruh dari pencemaran yang disebabkan oleh perkembangan industri yang ada di pesisir, limbah pertambangan atau transportasi kapal. Maraknya pertambangan emas skala kecil pada masyarakat terutama di Area Ratatotok oleh karena dapat meningkatkan pendapatan masyarakat secara cepat. Namun limbahnya tidak diolah, melainkan langsung dibuang ke sungai. Hal ini dapat menimbulkan dampak yang kurang baik bagi lingkungan dan kesehatan manusia (Wardhana, 2001). Limbah yang dibuang mengandung beragam logam baik yang digunakan dalam proses amalgamasi ataupun logam yang terikut dalam proses penggalian.

Alga merupakan salah satu sumber hayati laut yang perlu dieksploitasi seperti makroalga karena kaya akan senyawa-senyawa yang esensial untuk kehidupan berbagai organisme dan manusia. Pada umumnya makroalga kaya akan zat-zat nutrisi yang mengandung pigmenpigmen klorofil dan karotenoid. Pigmen selain berfungsi dalam proses fotosintesis juga mempunyai senyawa bioaktif yang berguna bagi manusia (Dawes, 1981). Berdasarkan hal tersebut maka penelitian ini bertujuan menganalisis logam yang terkandung dalam air, sedimen, thallus dari alga Padina australis Hauck, serta kandungan klorofil yang diambil dari Perairan Teluk Totok dan Perairan Blongko.

\section{METODE PENELITIAN}

Pengambilan sampel species alga Padina australis Hauck (Trono Jr., G.C. dan Ganzon-Fortes. 1988) dilakukan di dua perairan yaitu Perairan Teluk Totok dan Perairan Blongko. Perairan tersebut dipilih karena Perairan Teluk Totok diketahui merupakan daerah yang memiliki aktifitas pertambangan emas skala kecil (PESK), dan aktifitas tambang tersebut diduga turut menyumbang tingginya kandungan logam di Perairan Teluk Totok, salah satunya logam timbal (Pb). Perairan Blongko merupakan kontrol karena kondisi perairan masih terawat dengan baik dan Perairan Blongko adalah salah satu Daerah Perlindungan Laut (DPL) yang ditetapkan berdasarkan

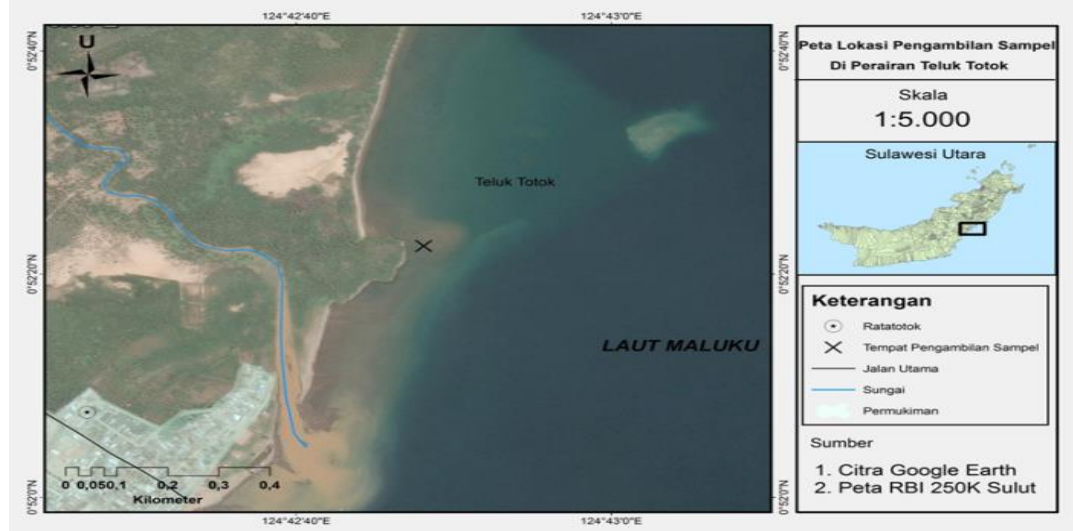

Gambar 1. Lokasi pengambilan sampel (Perairan Teluk Totok) 


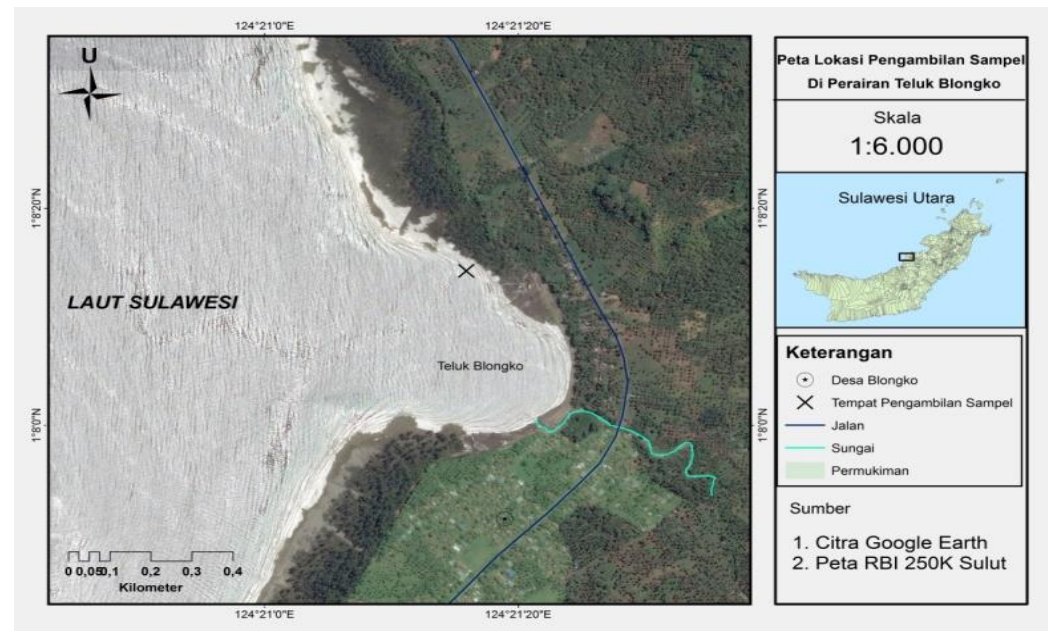

Gambar 2. Lokasi Pengambilan sampel (Perairan Blongko)

Keputusan Pemerintah Desa Blongko Nomor : 04/2004A/KDDB/XI/99, oleh karena itu Perairan Teluk Totok dan Perairan Blongko merupakan daerah yang tepat untuk menganalisis kandungan logam timbal pada air, sedimen, dan thallus alga Padina australis Hauck dan untuk mengetahui konsentrasi pigmen klorofil yang terkandung pada alga $P$. australis Hauck.

Pengujian analisis logam timbal $(\mathrm{Pb})$ pada air laut, sedimen dan thallus alga Padina australis Hauck berdasakan metode standar American
Public Health Association (APHA) yang dilakukan di Water Laboratory Nusantara (WLN) dengan menggunakan metode Examination of Water and Waste Water. Secara garis besar pengujian kandungan logam timbal $(\mathrm{Pb})$ pada air laut, sedimen dan thallus dilakukan dalam beberapa bagian yaitu :

1. Penetapan kadar air

Sampel air laut sebanyak $100 \mathrm{ml}$ disaring menggunakan kertas saring $0,45 \mu \mathrm{m}$ dan dimasukan pada corong pemisah kemudian ditambahkan 2 tetes asam nitrat (HNO) dan dihomogenkan.

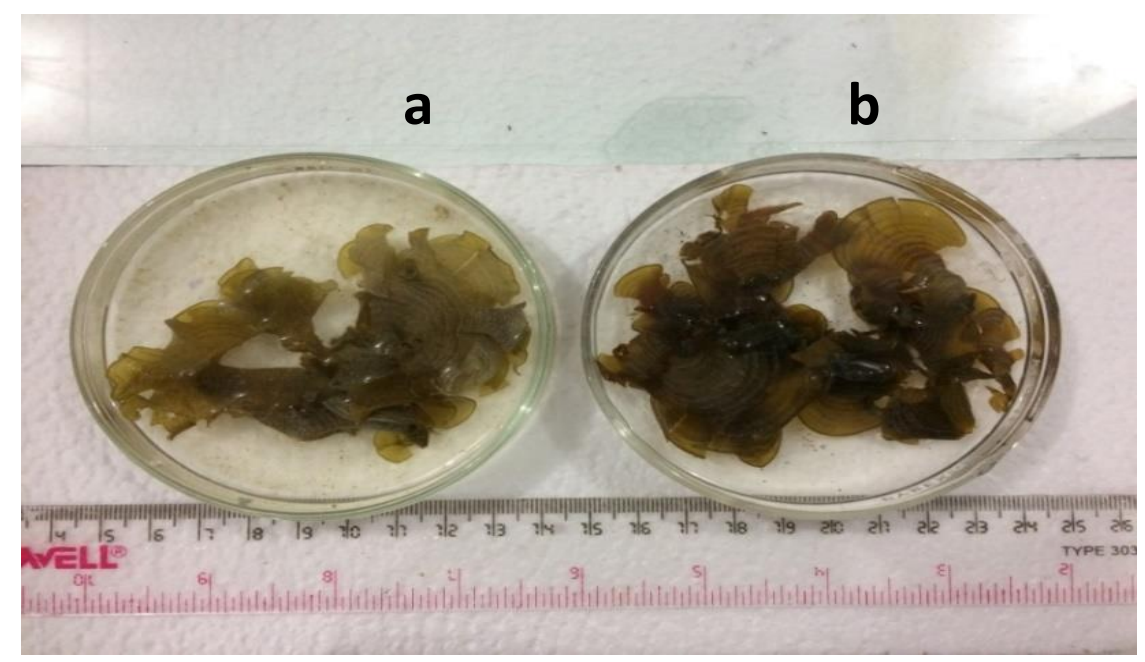

Gambar 3. Sampel alga P. australis Hauck : Perairan Blongko (a) perairan teluk Totok (b) 
Larutan HNO berfungsi untuk menurunkan $\mathrm{pH}$. Setelah itu, sampel air laut ditambahkan $1 \mathrm{ml}$ Amonium Pirolidin Ditiokarbonat (APDC), kemudian dihomogenkan. Pereaksi APDC berfungsi untuk membentuk senyawa organik komplek yang tidak larut pada fase air. Kemudian ditambahkan $10 \mathrm{ml}$ Metil Iso Butil Keton (MIBK), dihomogenkan selama 30 detik dan disimpan hingga terbentuk dua lapisan. Fase organik ditampung untuk dianalisis menggunakan Atomic Absorbtion Spektrofotometer (AAS).

\section{Analisis logam pada sedimen}

Sampel sedimen dikeringkan menggunakan freez dryer. Selanjutnya sampel sedimen dihaluskan menggunakan cawan porselin, ditimbang sebanyak 2 gram dan dimasukkan ke dalam gelas beker 100 $\mathrm{ml}$. Sampel sedimen ditambah $10 \mathrm{ml}$ $\mathrm{HNO}_{3}$ dan dipanaskan menggunakan hotplat pada suhu $85^{\circ} \mathrm{C}$. Ketika volume larutan tersisa 1-2 ml, larutan didinginkan. Setelah itu ditambahkan $10 \mathrm{ml} \mathrm{HNO}_{3}$ dan $10 \mathrm{ml} \mathrm{HClO}_{4}$. Pereaksi $\mathrm{HNO}_{3}$ dan $\mathrm{HClO}_{4}$ berfungsi untuk memutus ikatan logam berat dengan bahan organik pada sampel. Selanjutnya sampel sedimen dihomogenkan dan dipanaskan kembali pada hotplate sampai uap $\mathrm{HClO}_{4}$ hilang. Jika larutan sudah jernih, ditambahkan $100 \mathrm{ml}$ akuades untuk pengenceran, kemudian disaring menggunakan kertas saring 0,45 $\mu \mathrm{m}$. Hasil saringan selanjutnya dianalisis menggunakan AAS.

3. Analisis logam pada thallus alga P. australis Hauck

Sampel alga $P$. australis Hauck dikeringkan menggunakan freez dryer. Selanjutnya sampel $P$. australis Hauck dihaluskan menggunakan cawan porselin, ditimbang sebanyak 2 gram dan dimasukkan dalam gelas beker $100 \mathrm{ml}$. Sampel P. australis Hauck ditambah $10 \mathrm{ml} \mathrm{HNO}_{3}$ dan dipanaskan menggunakan hotplat pada suhu $85^{\circ} \mathrm{C}$.
Ketika volume larutan tersisa 1-2 ml, larutan didinginkan, setelah itu ditambahkan $10 \mathrm{ml} \mathrm{HNO}_{3}$ dan $10 \mathrm{ml}$ $\mathrm{HClO}_{4}$. Pereaksi $\mathrm{HNO}_{3}$ dan $\mathrm{HClO}_{4}$ berfungsi untuk memutus ikatan logam berat dengan bahan organik pada sampel. Selanjutnya sempel $P$. australis Hauck dihomogenkan dan dipanaskan kembali pada hotplate sampai uap $\mathrm{HClO}_{4}$ hilang. Jika larutan sudah jernih, ditambahkan $100 \mathrm{ml}$ akuades untuk pengenceran, kemudian disaring menggunakan kertas saring $0,45 \mu \mathrm{m}$. Hasil saringan selanjutnya dianalisis menggunakan AAS.

4. Analisis pigmen pada alga $P$. australis Hauck

Sampel alga ditimbang 0,5 gram kemudian direndam dalam larutan aseton analisis sebanyak $10 \mathrm{ml}$ lalu digerus. Hasil gerusan kemudian disaring dan dimasukkan dalam labu pemisah. Hasil ekstraksi tersebut dimasukkan dalam masing-masing tabung reaksi yang telah ditandai dengan kertas label kemudian dianalisis dengan spektrofotometer. Perhitungan konsentrasi klorofil dengan memakai rumus dari Jeffrey \& Humphrey, (1975).

\section{HASIL DAN PEMBAHASAN}

\section{Analisis Logam Timbal ( $\mathrm{Pb})$}

Analisis konsentrasi timbal $(\mathrm{Pb})$ dalam thallus $P$. australis Hauck dari Perairan Teluk Totok sebesar 3,8 ppm, lebih tinggi jika dibandingkan dengan konsentrasi timbal $(\mathrm{Pb})$ dalam thallus $P$. australis Hauck dari Perairan Blongko sebesar 1,1 ppm. Konsentrasi timbal $\mathrm{Pb}$ ) dalam sedimen di Perairan Teluk Totok 22,6 ppm jauh lebih tinggi jika dibandingkan dengan konsentrasi timbal $(\mathrm{Pb})$ dalam sedimen di Perairan Blongko yaitu 4,4 ppm. Konsentrasi timbal $(\mathrm{Pb})$ tidak terdeteksi dalam air laut di Perairan Teluk Totok dan Perairan Blongko karena logam timbal $(\mathrm{Pb})$ langsung mengendap di dasar 


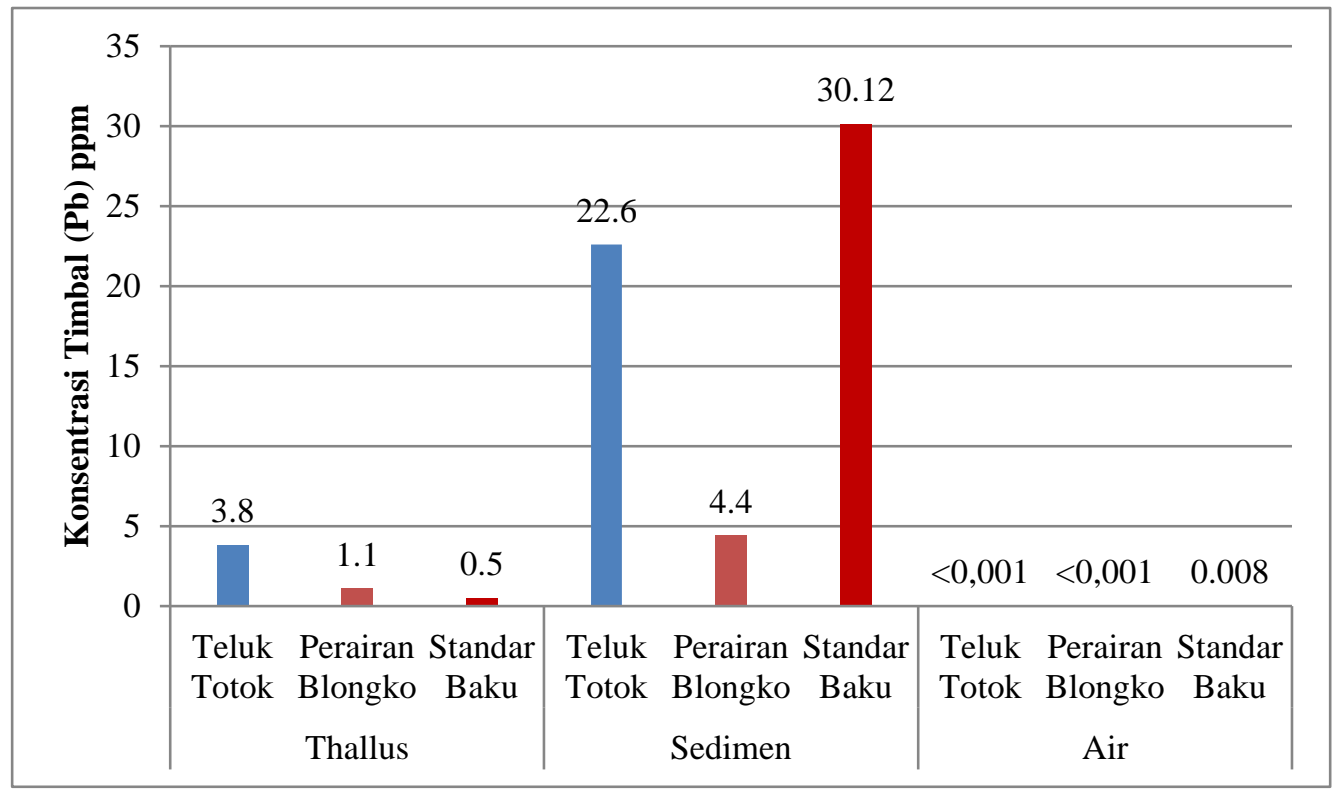

Gambar 4. Konsentrasi Timbal $(\mathrm{Pb})$ dalam Thallus Alga, Sedimen dan Air di Perairan Teluk Totok dan Perairan Blongko

perairan dan air laut selalu bergerak mengikuti arus. (Gambar 4). Konsentrasi timbal $(\mathrm{Pb})$ pada thallus $P$. australis Hauck di Perairan Teluk Totok dan Perairan Blongko berada di atas standar baku mutu SNI No. 7387 Tahun 2009 sebesar 0,5 ppm, sedangkan konsentrasi timbal (Pb) di sedimen Perairan Blongko jauh lebih rendah jika dibandingkan dengan standar baku mutu Canadian Council of Ministers of the Environment (CCME) sebesar 30,12 ppm, sama halnya juga dengan konsentrasi timbal $(\mathrm{Pb})$ di Perairan Teluk Totok masih berada di bawah standar baku CCME namun keberadaan timbal $(\mathrm{Pb})$ telah terdeteksi dan perlu mendapat perhatian dari pemerintah dan masyarakat. Konsentrasi timbal $(\mathrm{Pb})$ di badan air Perairan Teluk Totok maupun di Perairan Blongko masih berada di bawah Standar Baku Mutu berdasarkan Keputusan Menteri Lingkungan Hidup No. 51 Tahun 2004 sebesar 0,008 ppm.

Tingginya konsentrasi timbal $(\mathrm{Pb})$ di sedimen Perairan Teluk Totok jika dibandingkan dengan konsentrasi timbal $(\mathrm{Pb})$ di Perairan Blongko diasumsikan bersumber dari aktivitas pertambangan terutama logam ikutan dalam proses penggalian, aktivitas transportasi kapal di sekitar Teluk Totok, limbah rumah tangga dan terdapat secara alamiah di alam.

Terdeteksinya konsentrasi timbal $(\mathrm{Pb})$ dalam thallus $P$. australis Hauck mengindikasikan telah terjadi proses penyerapan timbal $(\mathrm{Pb})$ oleh $P$. australis Hauck yang terakumulasi dalam thallus dan hal ini dapat diasumsikan bahwa semakin tinggi timbal $(\mathrm{Pb})$ dalam sedimen maka semakin tinggi pula penyerapan timbal oleh P. Australis Hauck. Hasil penelitian Praveen dkk. (2014), menunjukkan bahwa daya serap alga laut terhadap $\mathrm{Pb}$ lebih besar dibandingkan $\mathrm{Cd}, \mathrm{Cu}$ dan Ni. Berdasarkan hasil penelitian Nasprianto (2017), konsentrasi timbal pada alga jenis Halimeda opuntia sebesar 2,2 ppm. Pada prinsipnya logam berat mempengaruhi tumbuhan dengan cara mengganti kedudukan ionion esensial dalam sel yang pada akhirnya akan mengganggu proses metabolisme dan menurunkan produktifitas rumput laut. 


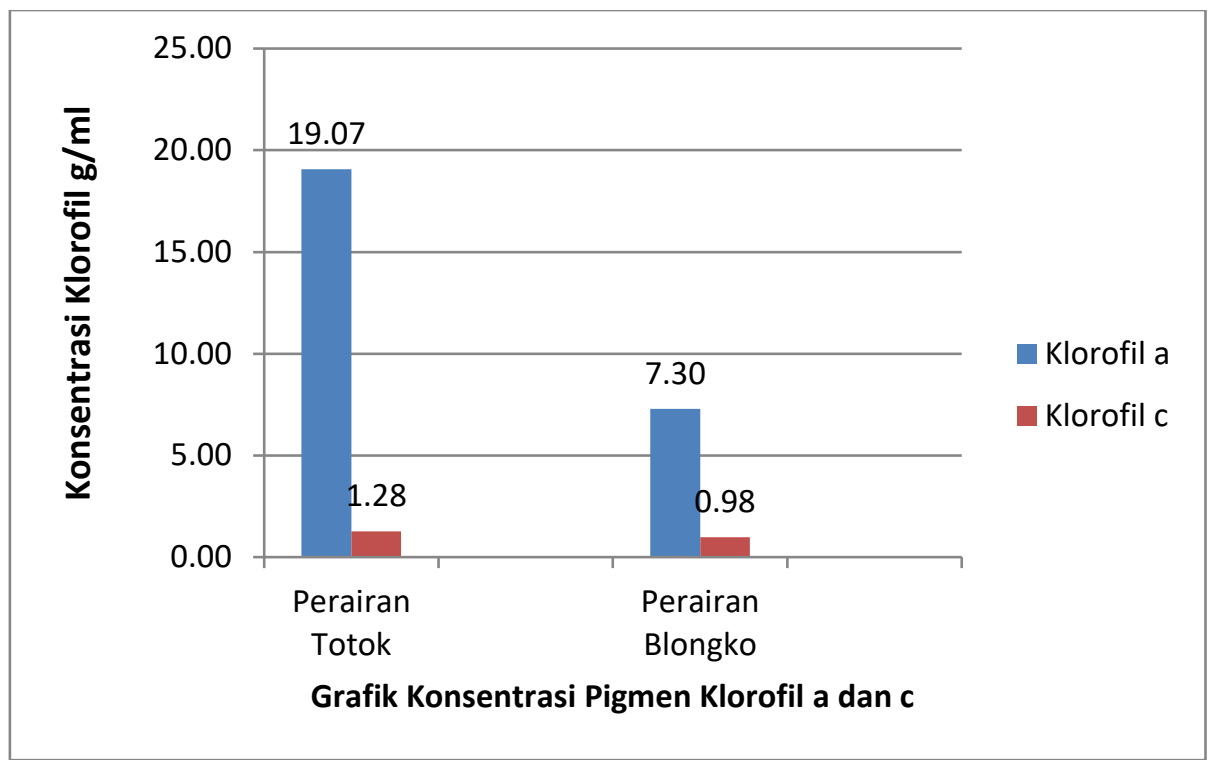

Gambar 5. Konsentrasi pigmen klorofil a dan c pada $P$. australis Hauck dari Perairan teluk Totok dan perairan Blongko

\section{Konsentrasi Pigmen Klorofil}

Hasil penelitian menunjukkan rata-rata hasil konsentrasi klorofil-a dengan tiga kali pengulangan di Perairan Teluk Totok adalah $19,07 \mathrm{~g} / \mathrm{ml}$ jauh lebih tinggi jika dibandingan dengan konsentrasi rata-rata klorofil-a dari Perairan Blongko yaitu 7,30 g/ml. Hal ini juga sama dengan konsentrasi rata-rata klorofil-c di Perairan Teluk Totok lebih tinggi dengan konsentrasi $1,28 \mathrm{~g} / \mathrm{ml}$ jika dibandingkan dengan konsentrasi rata-rata klorofil-c di Perairan Teluk Totok yaitu $0,98 \mathrm{~g} / \mathrm{ml}$ (Gambar 5).

Tingginya nilai konsentrasi klorofil-a dari Perairan Teluk Totok mengindikasikan bahwa pigmen klorofil merupakan faktor utama bertahannya alga $P$. australis Hauck di dalam kondisi perairan yang tercemar. Pigmen klorofil-a merupakan pigmen utama dalam proses fotosintesis (Dawes, 1981). Pigmen klorofil-c adalah pigmen aksesoris yang menangkap cahaya kemudian di proses dan di metabolisme oleh klorofil-a (Jupin dan Lamant, 1997). Klorofil-c akan berfungsi maksimal jika cuaca dalam kondisi mendung, tetapi oleh karena cuaca di
Perairan Totok dalam kondisi cerah maka konsentrasi klorofil-c lebih rendah dibandingkan dengan klorofil-a.

\section{KESIMPULAN}

1. Analisis konsentrasi timbal (Pb) dalam thallus $P$. australis Hauck di Perairan Teluk Totok lebih tinggi jika dibandingkan dengan konsentrasi timbal $(\mathrm{Pb})$ dalam thallus $\quad P$. australis Hauck di Perairan Blongko. Demikian juga konsentrasi timbal $(\mathrm{Pb})$ dalam sedimen. Konsentrasi timbal $(\mathrm{Pb})$ dalam air laut di Perairan Teluk Totok dan Perairan Blongko tidak terdeteksi.

2. Rata-rata hasil analisis konsentrasi klorofil-a di Perairan Teluk Totok jauh lebih tinggi jika dibandingan dengan konsentrasi rata-rata klorofil-a dari Perairan Blongko, dan berbanding terbalik dengan konsentrasi rata-rata klorofil-c di Perairan Blongko.

\section{DAFTAR PUSTAKA}

[APHA] American Public Health Association. 2005. Standard Methods For the Examination of 
Water and Wastewater. Amer . Publ. 17th Edition. New York Health Association

Dawes, C.J. 1981. Marine Botany. John Wiley and Sons University of South Florida. New York.

Jeffrey, S.W. Humphrey, G.F., 1975. New Spectrophotometric Equations For Determining Chlorophylls a, b, c1 and c2 Inb Higher Plants, Algae and Natural Phytoplankton. Biochem Physiol, 167(88):191 - 194.

Jupin, H. A. Lamant. 1999. La Photosynthèse. DUNOD. Paris.

Naspiranto, 2017 Kandungan Logam, Struktur Sel, Pigmen dan Antioksidan Pada Halimeda opuntia (Linnaeus) J.V.Lamouroux Dari Perairan Teluk Totok dan Perairan Perairan Blongko Sulawesi Utara. Tesis

Praveena, Jasmine R. Estherlydia, D 2014. Comparative Study of Phytochemical Screening and Antioxidant Capacities of Vinegar Made From Peel and Fruit Of Pineapple (Ananas Comosus L.). Food Chemistry and Food Processing, Loyola College, Chennai. International Journal of Pharma and Bio Sciences, 5(4):394-403.

Trono Jr., G.C.,Ganzon-Fortes. 1988. Phillippine Seaweds. National Book Store, Lnc. Phillippine.

Trono, G.C. 2004. Field Guide and Atlas of the Seaweed Resources of the Philippines. Book Mark. Makati City. Philippines.

Wardhana, W.A. 2001. Dampak Pencemaran Lingkungan.
Cetakan keempat. Yogyakarta: Penerbit ANDI. 